\title{
A combination of alfentanil-lidocaine-propofol provides better intubating conditions than fen- tanyl-lidocaine-propofol in the absence of muscle relaxants
}

\author{
[La combinaison d'alfentanil-lidocaïne-propofol fournit de meilleures conditions \\ d'intubation que celle de fentanyl-lidocaine-propofol en l'absence de myorelaxants]
}

Samar I. Jabbour-Khoury MD, Aliya S. Dabbous MD, Laudia B. Rizk MD, Naji M. Abou Jalad MD, Tonine E. Bartelmaos MD, Mohamad F. El-Khatib PhD, Anis S. Baraka MD FRCA

Purpose: To compare the ease of tracheal intubation without the use of muscle relaxants following an alfentanil-lidocaine-propofol sequence vs a fentanyl-lidocaine-propofol sequence.

Clinical features: In 80 ASA I and II adult patients undergoing elective laparoscopic surgery, we compared the intubating conditions following alfentanil $20 \mu \mathrm{g} \cdot \mathrm{kg}^{-1}$, lidocaine $1.5 \mathrm{mg} \cdot \mathrm{kg}^{-1}$, propofol 3 $\mathrm{mg} \cdot \mathrm{kg}^{-1}$ (Group I; $n=40$ ) vs fentanyl $2 \mu \mathrm{g} \cdot \mathrm{kg}^{-1}$, lidocaine 1.5 $\mathrm{mg} \cdot \mathrm{kg}^{-1}$, propofol $3 \mathrm{mg} \cdot \mathrm{kg}^{-1}$ (Group II; $n=40$ ). The intubating conditions were scored by jaw relaxation, vocal cord position and response to intubation, as well as by blood pressure and heart rate changes. The intubating conditions were good or excellent in $95 \%$ of patients in Group I vs 62.5\% of patients in Group II $(P<0.05)$. Blood pressure decreased from a preinduction value of $86 \pm 13$ $\mathrm{mmHg}$ to $72 \pm 28 \mathrm{mmHg}$ and $74 \pm 19 \mathrm{mmHg}$ in Group I, and from $85 \pm 12 \mathrm{mmHg}$ to $78 \pm 15 \mathrm{mmHg}$ and $78 \pm 12 \mathrm{mmHg}$ in Group II, one and five minutes following intubation $(P<0.05)$. This drop in blood pressure was not different between the two groups. Conclusion: An alfentanil-lidocaine-propofol sequence offers significantly better intubating conditions than a fentanyl- lidocainepropofol sequence in healthy adult patients.

Objectif : Comparer la facilité de l'intubation endotrachéale réalisée, sans recours aux myorelaxants, à la suite de l'administration de la séquence alfentanil-lidocaïne-propofol vs fentanyl-lidocaïne-propofol.

Éléments cliniques: Nous avons comparé, chez 80 adultes d'état physique ASA l et II devant subir une intervention laparoscopique réglée, les conditions d'intubation suivant l'administration de 20 $\mu \mathrm{g} \cdot \mathrm{kg}^{-1}$ d'alfentanil, I,5 $\mathrm{mg} \cdot \mathrm{kg}^{-1}$ de lidocaïne et $3 \mathrm{mg} \cdot \mathrm{kg}^{-1}$ de propofol (Groupe l; $n=40$ ) vs $2 \mu \mathrm{g} \cdot \mathrm{kg}^{-1}$ de fentanyl, I, $5 \mathrm{mg} \cdot \mathrm{kg}^{-1}$ de lidocaïne et $3 \mathrm{mg} \cdot \mathrm{kg}^{-1}$ de propofol (Groupe II ; n = 40). Les conditions d'intubation ont été cotées en fonction du relâchement de la mâchoire, de la position des cordes vocales et de la réponse à l'intubation, des changements de tension artérielle et de fréquence cardiaque. Ces conditions ont été bonnes ou excellentes chez $95 \%$ des patients du Groupe I vs 62,5 \% du Groupe II ( $P<0,05)$. II y a eu une baisse de la tension artérielle, par rapport aux valeurs enregistrées avant l'induction de $86 \pm 13 \mathrm{mmHg}$ à $72 \pm 28 \mathrm{mmHg}$ et $74 \pm 19 \mathrm{mmHg}$ dans le Groupe l, et de $85 \pm 12 \mathrm{mmHg}$ à $78 \pm 15 \mathrm{mmHg}$ à $78 \pm$ $12 \mathrm{mmHg}$ dans le Groupe II, une et cinq minutes après l'intubation ( $P$ $<0,05)$. Cette chute de la tension artérielle ne présentait pas de différence intergroupe.

Conclusion : Une séquence d'alfentanil-lidocaïne-propofol offre des conditions significativement meilleures qu'une séquence de fentanyllidocaïne-propofol chez des sujets adultes sains.

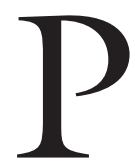

REVIOUS reports have shown that induction of anesthesia and tracheal intubation without the use of muscle relaxants can be achieved by agents like propofol ${ }^{1-3}$ and thiopental ${ }^{2-5}$ along with an opioid like fentanyl and alfentanil. ${ }^{1,3}$ Propofol has been reported to depress pharyngeal and laryngeal reactivity to a greater extent than equipotent doses of thiopental. ${ }^{2}$ Also, alfentanil has been shown to have a more rapid onset of action than fentanyl..$^{5,6}$ 
The present report compares the use of alfentanil $20 \mu \mathrm{g} \cdot \mathrm{kg}^{-1}$, lidocaine $1.5 \mathrm{mg} \cdot \mathrm{kg}^{-1}$, propofol $3 \mathrm{mg} \cdot \mathrm{kg}^{-1}$ vs fentanyl $2 \mu \mathrm{g} \cdot \mathrm{kg}^{-1}$, lidocaine $1.5 \mathrm{mg} \cdot \mathrm{kg}^{-1}$, propofol $3 \mathrm{mg} \cdot \mathrm{kg}^{-1}$ for induction of anesthesia and tracheal intubation without using muscle relaxants in adult patients undergoing elective surgery. The report scores the ease of tracheal intubation, as well as the blood pressure and heart rate changes following the two techniques.

\section{Methods}

After approval of the study by our institution Ethics Committee and obtaining patients' written consent, a total of 80 ASA I and II patients undergoing elective laparoscopic procedures (laparoscopic cholecystectomy and herniorraphy) were enrolled in the study. Patients aged between 20 and $60 \mathrm{yr}$, with a body mass index $(\mathrm{BMI})<30 \mathrm{~kg} \cdot \mathrm{m}^{2}$, and without a history or evidence of a difficult airway were included. Patients with a history or evidence of a difficult airway, as well as asthmatics and heavy smokers were excluded.

All patients were premedicated with glycopyrrolate $0.2 \mathrm{mg}$ im $45 \mathrm{~min}$ before induction of anesthesia. The study was conducted as a randomized and controlled trial. In the induction room, standard monitors including electrocardiogram, non-invasive blood pressure and pulse oximetry were placed. A crystalloid solution $(500-1000 \mathrm{~mL})$ was infused intravenously ten to $20 \mathrm{~min}$ before induction of anesthesia.

Patients were blindly randomized (by a toss of a coin) to one of two groups. Group I $(n=40)$ received an alfentanil-lidocaine-propofol sequence and Group II $(n=40)$ received a fentanyl-lidocaine-propofol sequence. In both groups, the following sequence was used for rapid induction of anesthesia: 1) preoxygenation for three minutes with $100 \%$ oxygen $\left(5 \mathrm{~L} \cdot \mathrm{min}^{-1}\right)$ using the carbon dioxide absorption circuit; 2) midazolam $0.03 \mathrm{mg} \cdot \mathrm{kg}^{-1} \mathrm{iv} ; 3$ ) two minutes after administration of midazolam, when the patients were sedated, either alfentanil $20 \mu \mathrm{g} \cdot \mathrm{kg}^{-1}$ (Group I) or fentanyl 2 $\mu \mathrm{g} \cdot \mathrm{kg}^{-1}$ (Group II) was injected $i v$ over 20-25 sec; 4) forty-five seconds after the injection of either alfentanil or fentanyl, lidocaine $1.5 \mathrm{mg} \cdot \mathrm{kg}^{-1} i v$ up to a maximum of $100 \mathrm{mg}$ was injected, to be followed immediately by propofol $3 \mathrm{mg} \cdot \mathrm{kg}^{-1} \mathrm{iv}$.

Rigid laryngoscopy was performed $45 \mathrm{sec}$ following propofol administration using a Macintosh blade size 3 . The anesthesiologist performing and scoring laryngoscopy and tracheal intubation was blinded to group assignment. Cuffed endotracheal tubes of 7 and $8 \mathrm{~mm}$ sizes were used in female and male patients respectively. When the trachea could not be intubated, rocuronium $0.5 \mathrm{mg} \cdot \mathrm{kg}^{-1}$ was administered intravenously.
Following tracheal intubation in all patients, the tracheal cuff was gently inflated, and anesthesia was maintained at the discretion of the attending anesthesiologist.

The intubation score was graded by a single operator as excellent, good, poor or inadequate according to the following criteria: degree of jaw relaxation, vocal cord position and intubating response. ${ }^{7}$ Intubation score is shown in Table I; an intubation score of 3 was considered excellent, while 4-6 was good, 7-9 was poor, and 10-12 was inadequate. Also, the intubation time (calculated from the moment the laryngoscope was inserted until after the endotracheal tube was secured) was recorded. Blood pressure (systolic, diastolic) and heart rate were recorded by HP Ml205A OmniCare model 24 (Hewlett-Packard, Boelingen, Germany), prior to induction of anesthesia (during preoxygenation), as well as one and five minutes following tracheal intubation. Oxygen saturation was recorded by Ml190/1A Agilent (Hewlett-Packard, Boelingen, Germany) reusable pulse oximetry transducers throughout the procedure. Complications during tracheal intubation such as coughing, laryngospasm, bronchospasm and generalized rigidity were recorded.

All data are reported as mean $\pm S D$, except the intubation scores. The Fisher exact test was used to compare the intubation scores. All other data were compared using the Student's t test and the ANOVA test. $P<0.05$ was considered significant. The intubation condition was used as the primary outcome in performing the power analysis for determination of the sample size. A $50 \%$ reduction in the intubation time and in the occurrence of poor and inadequate intubation conditions was used in computing the power analysis. Also, a type I error of $5 \%$ as well as a type II error of $20 \%$ were used in the power analysis. The results of the power analysis indicated that a minimum of 40 patients were needed in each group.

\section{Results}

\section{Demographic data}

The demographic data are shown in Table II. No significant difference was found between the two groups in terms of gender distribution, mean patient body weight and age, as well as ASA category.

\section{Intubation scores}

The intubation scores in the two groups are shown in Table III. Excellent intubating conditions (intubation score $=3)$ were achieved in $29 / 40(72.5 \%)$ of patients in Group I vs 13/40 (32.5\%) of patients in Group II. Good intubating conditions (intubation score $=4-6$ ) were achieved in $9 / 40(22.5 \%)$ of patients in Group I vs 
TABLE I Intubation score

\begin{tabular}{|c|c|c|c|}
\hline Score & Jaw relaxation & $\begin{array}{l}\text { Vocal cords } \\
\text { position }\end{array}$ & $\begin{array}{l}\text { Intubating } \\
\text { response }\end{array}$ \\
\hline 1 & Fully relaxed & Widely open & None \\
\hline 2 & Mild resistance & Mid position & $\begin{array}{l}\text { Diaphragmatic } \\
\text { movement }\end{array}$ \\
\hline 3 & Tight but open & Moving but open & $\begin{array}{l}\text { Slight } \\
\text { coughing }\end{array}$ \\
\hline 4 & Impossible & Closed & $\begin{array}{l}\text { Severe } \\
\text { coughing }\end{array}$ \\
\hline
\end{tabular}

Excellent $=3 ;$ Good 4-6; Poor $=7-9 ;$ Inadequate $=10-12$.

TABLE II Patient characteristics

\begin{tabular}{lll}
\hline & Group I & Group II \\
\hline ASA I/II & $20 / 20$ & $29 / 11$ \\
Male/female & $19 / 21$ & $20 / 20$ \\
Weight $(\mathrm{kg})$ & $71 \pm 14$ & $72 \pm 14$ \\
Age (yr) & $32 \pm 10$ & $33 \pm 9$ \\
\hline
\end{tabular}

TABLE III Intubation condition

\begin{tabular}{lll}
\hline Score & Group I & Group II \\
\hline Excellent & 29 & 13 \\
Good & 9 & 12 \\
Poor & 2 & 8 \\
Inadequate & 0 & 7 \\
Total & 40 & 40 \\
\hline
\end{tabular}

$12 / 40(47.5 \%)$ of patients in Group II. The total of acceptable intubating conditions (i.e., excellent and good) was 38/40 patients (95\%) in Group I, as compared to $25 / 40$ patients $(62.5 \%)$ in Group II $(P<0.05)$.

Poor intubating conditions (intubation score $=$ 7-9) as judged by poor jaw relaxation, mobile vocal cords, and slight coughing were observed in $2 / 40$ $(5 \%)$ of patients in Group I vs 8/40 (20\%) of patients in Group II. Inadequate intubating conditions (intubation score $=10-12)$ were observed in $7 / 40(17.5 \%)$ of patients in Group II and in no patient in Group I. Three of these seven patients in Group II had a tight jaw, moving vocal cords, and exhibited severe bucking and coughing following tracheal intubation. The trachea of the remaining four patients could not be intubated because of poor jaw relaxation and tightly closed vocal cords; in those patients, $0.5 \mathrm{mg} \cdot \mathrm{kg}^{-1}$ rocuronium was required for tracheal intubation.

The intubating time was significantly shorter $(P<$ $0.05)$ in Group I $(22 \pm 12 \mathrm{sec})$ compared to Group II $(41 \pm 34 \mathrm{sec})$.

\section{Hemodynamic values}

As shown in Table IV, mean arterial blood pressure decreased significantly in Groups I and II The drop in blood pressure was not different between the two groups. In both groups, there was no significant change in the heart rate following induction of anesthesia and tracheal intubation.

Oxygen saturation before, as well as following induction of anesthesia and tracheal intubation ranged between 96-100\%. No laryngospasm, coughing, aspiration, masseter spasm or generalized rigidity were noted in the two groups.

\section{Discussion}

The present study shows that intubating conditions in the absence of muscle relaxants in adult patients with favourable airway anatomy are better with an alfentanil $\left(20 \mu \mathrm{g} \cdot \mathrm{kg}^{-1}\right)$; lidocaine $\left(1.5 \mathrm{mg} \cdot \mathrm{kg}^{-1}\right)$; propofol $\left(3 \mathrm{mg} \cdot \mathrm{kg}^{-1}\right)$ sequence than when fentanyl $2 \mu \mathrm{g} \cdot \mathrm{kg}^{-1}$ is used instead of alfentanil. Also, intubating time in the alfentanil sequence is significantly shorter compared to the fentanyl sequence. In the fentanyl group, $10 \%$ of patients could not be intubated, suggesting that a fentanyl-lidocaine-propofol sequence might not be an adequate technique for tracheal intubation without muscle relaxants.

The better intubating scores and the shorter intubating time in the alfentanil group may be attributed to the more rapid onset of action of alfentanil than fentanyl. Camu investigated the distribution and elimination of alfentanil and observed a rapid distribution of the drug within the brain and highly perfused organs, followed by a displacement to a remote peripheral compartment. ${ }^{5}$ These findings can explain the rapid onset of unconsciousness previously reported to occur within $50 \mathrm{sec}$ of alfentanil induction and the short duration of action of the drug. ${ }^{5}$

Scott et al. showed that respiratory depression starts one to two minutes following an alfentanil 1500 $\mu \mathrm{g} \cdot \mathrm{min}^{-1}$ infusion, compared to three and five minutes following a fentanyl $150 \mu \mathrm{g} \cdot \mathrm{min}^{-1}$ infusion. ${ }^{6}$ Also, loss of consciousness occurs almost simultaneously with the onset of apnea in the alfentanil group, compared to a 30-60 sec temporal lag or hysteresis in the fentanyl group. ${ }^{6}$ According to Scott et al., lipid solubility can be a rate-limiting factor in the onset of effect. ${ }^{6}$ However, both alfentanil and fentanyl appear to have adequate lipid solubility to allow rapid blood- brain barrier penetration. ${ }^{6}$ Although fentanyl is more lipid soluble than alfentanil, the authors speculate that this higher lipid solubility would result in fentanyl having a larger depot to fill before the concentration of the free drug at the receptor site is adequate to achieve a 
TABLE IV Mean arterial pressure (MAP) and heart rate (HR) before induction of anesthesia and following tracheal intubation

\begin{tabular}{|c|c|c|c|c|c|c|}
\hline & \multicolumn{2}{|c|}{ Preinduction } & \multicolumn{2}{|c|}{1 min after intubation } & \multicolumn{2}{|c|}{5 min after intubation } \\
\hline & $\begin{array}{l}M A P \\
(m m H g)\end{array}$ & $\begin{array}{l}H R \\
\text { (beats.min }{ }^{-1} \text { ) }\end{array}$ & $\begin{array}{l}M A P \\
(m m H g)\end{array}$ & $\begin{array}{l}H R \\
\text { (beats. } \text { min }^{-1} \text { ) }\end{array}$ & $\begin{array}{l}M A P \\
(m m H g)\end{array}$ & $\begin{array}{l}\text { HR } \\
\text { (beats.min }\end{array}$ \\
\hline $\begin{array}{l}\text { Alfentanil } \\
\text { group } n=40\end{array}$ & $86 \pm 13$ & $91 \pm 27$ & $72 \pm 28^{*}$ & $91 \pm 21$ & $74 \pm 19 *$ & $84 \pm 23$ \\
\hline $\begin{array}{l}\text { Fentanyl } \\
\text { group } n=40\end{array}$ & $85 \pm 12$ & $90 \pm 14$ & $78 \pm 15^{*}$ & $92 \pm 17$ & $78 \pm 12^{*}$ & $91 \pm 15$ \\
\hline
\end{tabular}

${ }^{*} P<0.05 v s$ baseline.

narcotic effect. ${ }^{6}$ In contrast, alfentanil with fewer storage sites to fill would be able to achieve sooner a higher concentration of free drug at opioid receptor sites, thus explaining its more rapid onset. ${ }^{6}$

Following an $i v$ bolus, previous reports have estimated that alfentanil is three to ten times less potent than fentanyl. ${ }^{6}$ In our report, we elected to compare 20 $\mu \mathrm{g} \cdot \mathrm{kg}^{-1}$ alfentanil with $2 \mu \mathrm{g} \cdot \mathrm{kg}^{-1}$ fentanyl. Scheller et al. compared different doses of alfentanil $\left(30 \mu \mathrm{g} \cdot \mathrm{kg}^{-1}, 40\right.$ $\left.\mu \mathrm{g} \cdot \mathrm{kg}^{-1}, 50 \mu \mathrm{g} \cdot \mathrm{kg}^{-1}, 60 \mu \mathrm{g} \cdot \mathrm{kg}^{-1}\right)$, in combination with propofol $2 \mathrm{mg} \cdot \mathrm{kg}^{-1}$ for tracheal intubation, and concluded that at least $40 \mu \mathrm{g} \cdot \mathrm{kg}^{-1}$ of alfentanil is needed to achieve intubating conditions similar to that achieved with thiamylal and succinylcholine. ${ }^{1}$ Also, a significant number of patients $(5 / 15)$ in the $30 \mu \mathrm{g} \cdot \mathrm{kg}^{-1}$ group required succinylcholine for tracheal intubation. ${ }^{1}$ These results are different from our findings showing that alfentanil $20 \mu \mathrm{g} \cdot \mathrm{kg}^{-1}$ can provide adequate intubating conditions when combined with lidocaine $1.5 \mathrm{mg} \cdot \mathrm{kg}^{-1}$ and propofol $3 \mathrm{mg} \cdot \mathrm{kg}^{-1}$. In addition, none of the patients in the alfentanil group required muscle relaxants for tracheal intubation.

The good or excellent intubating conditions achieved in our report, despite using a smaller dose of alfentanil, can be attributed to the use of a higher dose of propofol $\left(3 \mathrm{mg} \cdot \mathrm{kg}^{-1}\right)$. Propofol in a dose of 2.5 $\mathrm{mg} \cdot \mathrm{kg}^{-1}$ has been shown to depress laryngeal reflexes to a greater extent than an equipotent dose of thiopentone and to provide satisfactory conditions for tracheal intubation. ${ }^{2}$ Also, the use of lidocaine (1.5 $\mathrm{mg} \cdot \mathrm{kg}^{-1}$ ) has been shown to decrease the cough reflex and may decrease the incidence of post-laryngoscopy hypertension and tachycardia. ${ }^{8}$

Muscle rigidity following opiate administration has been studied in human volunteers, and previous reports show that rigidity occurs in $80 \%$ of patients when $175 \mu \mathrm{g} \cdot \mathrm{kg}^{-1}$ of alfentanil ${ }^{9}$ are administered, and in $50 \%$ of patients when $15 \mu \mathrm{g} \cdot \mathrm{kg}^{-1}$ fentanyl was used. ${ }^{10}$ The absence of muscle rigidity in our study can be attributed to the much lower dosages of narcotics used (alfentanil $20 \mu \mathrm{g} \cdot \mathrm{kg}^{-1}$ or fentanyl $2 \mu \mathrm{g} \cdot \mathrm{kg}^{-1}$ ). Also, our injection rate of the narcotics was slow $(20-25 \mathrm{sec})$, since there is evidence that the incidence and severity of opiate-induced rigidity is not only dependent on the dosage but also on the rate of administration. ${ }^{1}$ In addition, benzodiazepines lower the dose of narcotic required for intubation, and may secondarily decrease the incidence of rigidity. ${ }^{11}$

Following induction of anesthesia and tracheal intubation, we observed a significant drop in the mean blood pressure down to $72 \pm 28 \mathrm{mmHg}$ in Group I and to $78 \pm 15 \mathrm{mmHg}$ in Group II. The large standard deviations suggest that some patients had a high blood pressure while others had a low blood pressure. However, the mean drop in blood pressure was not different between the two groups. The administration of propofol in a dose of $2-2.5 \mathrm{mg} \cdot \mathrm{kg}^{-1}$ is expected to lower mean blood pressure by $25-40 \% .^{12}$ This drop is secondary to both the vasodilator and the myocardial depressant effects of propofol. ${ }^{12}$

In view of the drop in mean arterial pressure observed in our patients, this technique of tracheal intubation without muscle relaxants may not be appropriate for elderly patients and in patients with cardiovascular or cerebrovascular disease. Also, we would be reluctant to recommend a rapid sequence induction without the use of muscle relaxants in patients at risk of aspiration. Since patients are not paralyzed, active vomiting remains a possibility and cricoid pressure could result in serious harm.

In conclusion, induction of anesthesia and tracheal intubation without muscle relaxants is better accomplished in healthy adult patients undergoing elective surgery with an alfentanil $20 \mu \mathrm{g} \cdot \mathrm{kg}^{-1}$; lidocaine 1.5 $\mathrm{mg} \cdot \mathrm{kg}^{-1}$; propofol $3 \mathrm{mg} \cdot \mathrm{kg}^{-1}$ sequence than with fentanyl $2 \mu \mathrm{g} \cdot \mathrm{kg}^{-1}$; lidocaine $1.5 \mathrm{mg} \cdot \mathrm{kg}^{-1}$; propofol 3 $\mathrm{mg} \cdot \mathrm{kg}^{-1}$. Both the intubation scores and the intubation times are better when alfentanil is used rather than fentanyl. Hemodynamic changes were similar in both groups. 


\section{References}

1 Scheller MS, Zornow MH, Saidman LJ. Tracheal intubation without the use of muscle relaxants: a technique using propofol and varying doses of alfentanil. Anesth Analg 1992; 75: 788-93.

2 Barker P, Langton JA, Wilson IG, Smith G. Movements of the vocal cords on induction of anaesthesia with thiopentone or propofol. Br J Anaesth 1992; 69: 23-5.

3 Hovorka J, Honkavaara P, Kortilla K. Tracheal intubation after induction of anaesthesia without thiopentone or propofol without muscle relaxants. Acta Anaesthesiol Scand 1991; 35: 326-8.

4 McKeating K, Bali I, Dundee J. The effects of thiopentone and propofol on upper airway integrity. Anaesthesia 1988; 43: 638-40.

5 Camu F, Gepts E, Rucquoi M, Heykarts J.

Pharmacokinetics of alfentanil in man. Anesth Analg 1982; 61: 657-61.

6 Scott JC, Ponganis KV, Stanski DR. EEG quantitation of narcotic effect: the comparative pharmacodynamics of fentanyl and alfentanil. Anesthesiology 1985; 62: 234-41.

7 Iamaroon A, Pitimana-aree S, Prechawai C, Anusit J, Somcharoen K, Chaiyaraj O. Endotracheal intubation with thiopental/succinylcholine or sevoflurane-nitrous oxide anesthesia in adults: a comparative study. Anesth Analg 2001; 92: 523-8.

8 Morgan GE, Mickail MS, Murray MJ. Airway Management. Clinical Anesthesiology, $3^{\text {rd }}$ ed. New York: Lange Medical Books/McGraw-Hill; 2002: 59-85.

9 Benthuysen JL, Smith NT, Sanford T, Head N, DecSilver $H$. Physiology of alfentanil-induced rigidity. Anesthesiology 1986; 64: 440-6.

10 Streisand JB, Bailey PL, LeMaire L, et al. Fentanylinduced rigidity and unconsciousness in human volunteers. Anesthesiology 1993; 78: 629-34.

11 McDonnell TE, Bartkowski RR, Williams JT. ED . $_{50}$ of alfentanil for induction of anesthesia in unpremedicated young adults. Anesthesiology 1984; 60: 136-40.

12 Reves JG, Glass PS, Lubarsky DA. Nonbarbiturate intravenous anesthetics. In: Miller $\mathrm{RD}(\mathrm{Ed})$. Anesthesia $5^{\text {th }}$ edition. Philadelphia: Churchill Livingstone; 2000 : 228-72. 